\title{
Effect of temperature on the reproduction of Bracon vulgaris Ashmead (Hymenoptera: Braconidae), a parasitoid of the cotton boll weevil
}

\author{
FRANCISCO S. RAMALhO ${ }^{1}$, PAUlO A. WANDERLEY ${ }^{2}$, José B. MALAQUias ${ }^{1}$, \\ FRANCISCO S. FERNANDES ${ }^{1}$, ANTÔNIO R.B. NASCIMENTO ${ }^{1}$ and JOSÉ C. ZANUNCIO ${ }^{3}$ \\ ${ }^{1}$ Embrapa Algodão, Unidade de Controle Biológico, Av. Osvaldo Cruz, 1143, 58107-720 Campina Grande, PB, Brasil \\ ${ }^{2}$ Instituto Federal de Educação, Ciências e Tecnologia - IFPB, Rua Presidente Tancredo Neves, s/n, 58800-970 Sousa, PB, Brasil \\ ${ }^{3}$ Departamento de Biologia Animal, Universidade Federal de Viçosa, Av. PH Rolfs, s/n, Campus Universitário, \\ 36570-000 Viçosa, MG, Brasil
}

Manuscript received on March 30, 2010; accepted for publication on December 21, 2010

\begin{abstract}
This research studied the effect of temperature on the reproduction of Bracon vulgaris Ashmead, an ectoparasitoid of cotton boll weevil (Anthonomus grandis Boheman) at constant temperatures of 20, 25 and $30^{\circ} \mathrm{C}, 70 \pm 10 \% \mathrm{RH}$ and a photophase of $14 \mathrm{~h}$. Females of the parasitoid produced a greater number of eggs when exposed to $25^{\circ} \mathrm{C}(124.65$ eggs) in relation to those exposed to $20(43.40 \mathrm{eggs})$ and $30^{\circ} \mathrm{C}(49.60 \mathrm{eggs})$. The number of parasitized larvae per female of B. vulgaris at $25^{\circ} \mathrm{C}(71.75)$ was greater than at $20^{\circ} \mathrm{C}(31.40)$ and $30^{\circ} \mathrm{C}(25.15)$. The daily intrinsic rates of increase $\left(\mathrm{r}_{\mathrm{m}}\right)$ were -0.007 at $20^{\circ} \mathrm{C}, 0.07$ at $25^{\circ} \mathrm{C}$ and 0.03 at $30^{\circ} \mathrm{C}$, revealing that the temperature of $25^{\circ} \mathrm{C}$ produced increases of 1,100 and $133 \%$ in the value $r_{m}$ in relation to temperatures of 20 and $30^{\circ} \mathrm{C}$, respectively. In programs of biological control of the boll weevil using innoculative releases, adult females of B. vulgaris with approximately five (at 25 or $30^{\circ} \mathrm{C}$ ) or 20 day old $\left(\right.$ at $20^{\circ} \mathrm{C}$ ) should be used; when using innundative releases, adult females of $\mathrm{B}$. vulgaris, with ages between 11 and $31 ; 9$ and 29 or 3 and 14 days, respectively, at 20,25 or $30^{\circ} \mathrm{C}$ should be used.
\end{abstract}

Key words: ectoparasitoid, Anthonomus grandis Boheman, biology, life and fertility tables.

\section{INTRODUCTION}

New alternatives for the control of the boll weevil, Anthonomus grandis Boheman (Coleoptera: Curculionidae) have arisen in recent years (Ramalho et al. 2009). Within the philosophy of Integrated Management of Pests, the biological control of the boll weevil through parasitoids is a tactic able of considerably reducing the damage that the pest can promote to cotton crop, without damaging the environment. So, the use of parasitoids emerges as an extremely relevant tactic to be employed together with other strategies within the management of the boll weevil in Brazil.

Studies carried out by Ramalho and Wanderley (1996) and Ramalho et al. (1996) showed that thirteen

Correspondence to: Francisco de Sousa Ramalho

E-mail: ramalhohvv@globo.com species of boll weevil parasitoids were found in the herbaceous and perennial cotton agro-ecosystems of Brazil. Ramalho et al. (1993) demonstrated that, in the Northeast of Brazil, the parasitoid Bracon vulgaris Ashmead (Hymenoptera: Braconidae) is the main agent responsible for the natural mortality of the boll weevil in cotton bolls. Therefore, in Brazil, the biological control of the boll weevil through the parasitoid $B$. vulgaris will be used on a very broad scale, when more is known about the bioecology of this parasitoid.

It is known that the parasitoid $B$. vulgaris is a major natural enemy that may be used in the decrease of boll weevil populations in the cotton agro-ecosystems of the Northeast of Brazil. On the other hand, temperature is one of the climatic factors that most directly affect the insects, determining the greater or lesser ex- 
tent of populations of pests and natural enemies in agricultural ecosystems (Kalaitzaki et al. 2007). The insect maintains its body temperature close to that of the environment. Thus, the optimum temperature is that for which the insect exhibits the more rapid development and higher number of descendants (Kalaitzaki et al. 2007, Ramalho et al. 2009).

Numerical changes in an insect population may be described through knowledge of birth, death and migration rates (Price 1997), and the construction of life tables is an appropriate way of describing these dynamics. This tool takes into account the duration and survival of different stages of development of the insect and, in combination with the daily data of female fertility, the size and age structure of an insect population at a given time may be determined (Southwood 1968). Thus, life tables are simplified reports on the life of a population of individuals throughout a generation (Price 1997). The reproductive aspect of the numerical response is measured as an increase in the reproductive rate of insect populations. In the case of insects, the rate of increase will depend on three components: age at reproduction (Andrewartha and Birch 1954), survival rate and fecundity (Beddington et al. 1976). Temperature influences these rates and the outcome of the parasitoid-host interaction (Hance et al. 2007). According to Reznik et al. (2009), numerous parameters (survival, lifetime fecundity, etc.) reach a maximum at a certain optimal temperature and a more or less symmetrically decrease toward both lower and upper limits of tolerance; moderate thermoperiods produce some "better" results than the mean temperatures.

Knowledge about the influence of temperature on the reproduction of the parasitoid $B$. vulgaris is crucial to programs of integrated management of $A$. grandis. Thus, with this research we aimed to analyze the fecundity of B. vulgaris in relation to age and three temperatures, as well as to estimate the statistics that makes up the life and fertility tables of B. vulgaris.

\section{MATERIALS AND METHODS}

The study was carried out at the Biological Control Unit of Embrapa Algodão in climatic chambers under constant temperatures of 20,25 and $30^{\circ} \mathrm{C}$, relative air humidity of $70 \pm 10 \%$ and photophase of $14 \mathrm{hs}$.
Age-Dependent Fecundity. Twenty newly emerged couples of B. vulgaris were studied at each of the three temperatures. Each couple was kept in a clear plastic box, measuring $10.5 \mathrm{~cm}$ in diameter and $5.5 \mathrm{~cm}$ in height. Every day each couple received distilled water, honey and five third-instar larvae of $A$. grandis sealed individually in parafilm cells, as described by Wanderley and Ramalho (1996). The supply of water and humidity to the parasitoid was done by placing a wad of cotton wool soaked in distilled water inside each plastic box. Honey was offered in its pure form to the parasitoids, in small drops distributed among the moulded parafilm cells using a disposable syringe.

Each couple of B. vulgaris was observed at a $24 \mathrm{~h}$ interval, and the number of dead adults, eggs laid by each parasitoid on $A$. grandis larva and parasitized larvae were recorded. The number of eggs and larvae parasitized were quantified with a stereomicroscope. The parasitized larvae, together with the parasitoid eggs, were placed in Petri dishes $(9.0 \times 1.5 \mathrm{~cm})$ and kept in climatic chambers under the same conditions of their parents until hatching of the $B$. vulgaris larvae.

Preoviposion and oviposition length, daily and maximum fecundity, number of parasitized larvae per female per day, and male and female longevity were recorded for 20 couples of $B$. vulgaris. The means were compared with the Student-Newman-Keul test $(P=$ $0.05)$.

The age-dependent fecundity of B. vulgaris was divided into three general periods, as described by Morales-Ramos and Cate (1992) for Catolaccus grandis (Burks) (Hymenoptera: Pteromalidae). The three periods included (1) the preovipositional period, which starts at emergence and ends with the first oviposition; (2) the fecundity plateau, which starts when $50 \%$ of the females reach maximum fecundity and ends when the oviposition rate of the females starts a constant decline; and (3) declining fecundity, which begins at the end of the fecundity plateau period and ends with the death of the female.

The fecundity plateau was determined from the cumulative oviposition of 20 female parasitoids. The declining fecundity period was determined by subtracting the age at which the fecundity plateau ended (when at least $60 \%$ of total fecundity was produced) from the mean longevity of the female. 
Life and Fertility Tables. The parameters that make up the life and fertility tables of adult parasitoids were calculated using data derived from the study described above.

Survival of immature stages was obtained from P.A. Wanderley, unpublished data, who used the same methodology from this study. The probabilities of survival from birth to age $\mathbf{x}\left(\mathbf{l}_{\mathbf{x}}\right)$ for all the immature stages and adult ages of the parasitoid were calculated.

The life expectancy was calculated by $\mathbf{e}_{\mathbf{x}}=\mathbf{T}_{\mathbf{x}} / \mathbf{l}_{\mathbf{x}}$ (Southwood 1968), where $\mathbf{T}_{\mathbf{x}}$ is the total number of insect $\mathrm{x}$ age units beyond the age $\mathrm{x}$, which is given by: $\mathbf{T}_{\mathbf{x}}$ $=\mathbf{L}_{\mathbf{x}}+\mathbf{L}_{\mathbf{x}+\mathbf{1}}+\mathbf{L}_{\mathbf{x}+\mathbf{2}} \ldots+\mathbf{L}_{\mathbf{w}}$, where $\mathbf{w}=$ the last age.

The intrinsic rate of population increase $\left(\mathbf{r}_{\mathrm{m}}\right)$ was calculated, using the Lotka equation (1907), i.e.:

$$
\sum_{\mathbf{x}=\mathbf{0}}^{\mathbf{w}} \mathbf{e}^{\left(-\mathbf{r}_{\mathbf{m}} \cdot \mathbf{x}\right)} \mathbf{1}_{\mathbf{x}} \mathbf{m}_{\mathbf{x}}=\mathbf{1}
$$

where $\mathbf{x}$ is the age group, $\mathbf{w}$ is the oldest age group, and $\mathbf{m}_{\mathbf{x}}$ is the number of females produced by a female aged $\mathbf{x}$.

The net reproductive rate $\left(\mathbf{R}_{\mathbf{0}}\right)$ is the number of females produced by a single female throughout its whole life and was calculated using the Krebs (1994) formula:

$$
\mathbf{R}_{\mathbf{0}}=\sum_{\mathbf{x}=\mathbf{0}}^{\mathbf{w}} \mathbf{1}_{\mathbf{x}} \mathbf{m}_{\mathbf{x}} .
$$

The generation time (GT) is the time taken by a parasitoid population to increase by a factor equal to the net reproductive rate, which is calculated using the formula: $\mathbf{G T}=\ln \left(\mathbf{R}_{\mathbf{0}}\right) / \mathbf{r}_{\mathbf{m}}$ (Carey 1993).

The time required by the parasitoid population to double the number of individuals (DT), was calculated using the formula: $\mathbf{D T}=\ln (\mathbf{2}) / \mathbf{r}_{\mathbf{m}}$ (Carey 1993).

The reproductive value $\left(\mathbf{R V}_{\mathbf{x}}\right)$, according to Carey (1993), is the contribution that a single female of age $\mathrm{x}$ will make to the future population. The analytic expression of the reproductive value of an individual of age $\left(\mathbf{R V}_{\mathbf{x}}\right)$ is given by the equation:

$$
\mathbf{R V}_{\mathbf{x}}=\left(\mathbf{e}_{\mathbf{m}}^{\mathbf{r}(\mathbf{x}+0.5)}\right) / \mathbf{l}_{\mathbf{x}} \sum_{\mathbf{y}=\mathbf{x}}^{\mathbf{w}} \mathbf{e}_{\mathbf{m}}^{-\mathbf{r}(\mathbf{y}+0.5)} \mathbf{l}_{\mathbf{y}} \mathbf{m}_{\mathbf{y}}
$$

where $\mathbf{r}_{\mathbf{m}}$ is the intrinsic rate of population increase; $\mathbf{l}_{\mathbf{x}}$ is the rate of survival of age 0 at the start of age $x, \mathbf{l}_{\mathbf{y}}$ is the rate of survival at age $y, \mathbf{m}_{\mathbf{y}}$ is the reproduction at age $y$ and $\mathrm{w}$ is the last age group.

\section{RESULTS AND DISCUSSION}

Age-Dependent Fecundity. The preoviposition period of $B$. vulgaris was much longer $(\mathrm{F}=17.62 ; P=0.05)$ at $20^{\circ} \mathrm{C}(8.55 \pm 0.91$ days $)$ than at $25(5.80 \pm 0.65$ days) and $30^{\circ} \mathrm{C}(3.80 \pm 0.53$ days) (Table I), suggesting a delay in the maturation of the eggs. This delay may be explained by temperature stress. In natural conditions, the preoviposition period of Bracon mellitor Say, a parasitoid of boll weevil, is 2 days (Adams et al. 1969). However, Barfield et al. (1977) stated that the preoviposition period of $B$. mellitor decreases with the increase in temperature, from 13.4 days (at $15.6^{\circ} \mathrm{C}$ ) to 4.96 days (at $32.2^{\circ} \mathrm{C}$ ). Engroff and Watson (1975) reported that the average preoviposition period of Bracon kirkpatricki (Wilkinson) varies from 6.9 (at $20^{\circ} \mathrm{C}$ ) to 2.5 days (at $35^{\circ} \mathrm{C}$ ) on boll weevil larvae. According to M.G. Rojas (unpublished data), although some females of Bracon compressitarsis Wharton begin oviposition at two days of age, this occurs with greater intensity from 4 to 5 days of age on boll weevil larvae. Between 24 and $27^{\circ} \mathrm{C}$, females of Catolaccus grandis (Burks), an ectoparasitoid of boll weevil, display a preoviposition period of 3 days (Johnson et al. 1973). Morales-Ramos and Cate (1992), using as host boll weevil larvae fed on an artificial diet, recorded an average period of preoviposition for C. grandis of 3.8 days at $25^{\circ} \mathrm{C}$, and 1.8 days at $30^{\circ} \mathrm{C}$. Therefore, with the increase in temperature occurs a more rapid maturing of the sexual organs of female parasitoids, reducing the period of preoviposition (Andrewartha and Birch 1954). Jervis et al. (2008) reported that the lifetime potential fecundity varies markedly among parasitoid species and may be high in some taxa (e.g., Braconidae, Ichneumonidae). Parasitoid species generally have a short preoviposition period, which in some cases is due to extreme synovigeny. However, thereafter, the temporal pattern of egg deposition resembles other species, except that the fecundity curve is depressed and lifetime realized fecundity is low (Jervis et al. 2008). However, there are other species that also emerge with no eggs; they may have a long preoviposition period (due to extreme synovigeny), and lay eggs at a lower rate, but for an extended period of time (Jervis et al. 2008). Important trade-offs have been observed among parasitoid wasps. Blackburn's (1991a, b) comparative 
TABLE I

Influence of temperature (mean $\pm S E)^{\mathbf{I}}$ on biological variables of Bracon vulgaris (Hymenoptera: Braconidae) females with boll weevil larvae obtained from cotton bolls at $70 \pm 10 \% \mathrm{RH}$ and photoperiod of 14:10 (L:D) $h$.

\begin{tabular}{l|c|c|c}
\hline \multirow{2}{*}{ Biological variables } & \multicolumn{3}{c}{ Temperature $\left({ }^{\circ} \mathrm{C}\right)$} \\
\cline { 2 - 4 } & 20 & 25 & 30 \\
\hline Preoviposition period (day) & $8.55 \pm 0.91 \mathrm{a}$ & $5.80 \pm 0.65 \mathrm{~b}$ & $3.80 \pm 0.53 \mathrm{~b}$ \\
\hline Oviposition period (day) & $25.25 \pm 3.71 \mathrm{ab}$ & $30.30 \pm 2.93 \mathrm{a}$ & $13.55 \pm 1.81 \mathrm{~b}$ \\
\hline Eggs/female (no.) & $43.40 \pm 9.58 \mathrm{~b}$ & $124.65 \pm 15.27 \mathrm{a}$ & $49.60 \pm 8.49 \mathrm{~b}$ \\
\hline Eggs/female/day (no.) & $0.96 \pm 0.16 \mathrm{~b}$ & $3.06 \pm 0.28 \mathrm{a}$ & $2.66 \pm 0.18 \mathrm{c}$ \\
\hline Eggs/larva (no.) & $1.39 \pm 0.04 \mathrm{a}$ & $1.75 \pm 0.06 \mathrm{~b}$ & $1.96 \pm 0.02 \mathrm{c}$ \\
\hline Parasitized larvae/female (no.) & $31.40 \pm 7.40 \mathrm{~b}$ & $71.75 \pm 6.82 \mathrm{a}$ & $25.15 \pm 4.03 \mathrm{~b}$ \\
\hline Parasitized larvae/female/day (no.) & $0.69 \pm 0.11 \mathrm{~b}$ & $1.75 \pm 0.14 \mathrm{a}$ & $1.24 \pm 0.18 \mathrm{ac}$ \\
\hline Fecundity plateau (day) & $11-28$ & $9-27$ & $3-14$ \\
\hline Declining fecundity period (day) & $29-43$ & $28-41$ & $15-21$ \\
\hline High parasitism (day) & $11-31$ & $9-29$ & $3-14$ \\
\hline Female longevity (day) & $42.60 \pm 4.17 \mathrm{a}$ & $41.10 \pm 2.73 \mathrm{a}$ & $21.20 \pm 1.67 \mathrm{~b}$ \\
\hline Male longevity (day) & $27.35 \pm 3.09 \mathrm{a}$ & $31.55 \pm 1.79 \mathrm{a}$ & $13.30 \pm 1.16 \mathrm{~b}$ \\
\hline
\end{tabular}

analysis revealed a fast-slow continuum in a suite of key reproductive and related traits among 474 species. Fast parasitoid taxa were typically more fecund, produced smaller eggs, laid these eggs more rapidly into hosts, and reproduced earlier in life (correlated with shorter preoviposition periods) than slow taxa. Moreover, more fecund parasitoid species and/or those that invest more in early life reproduction have shorter life spans than parasitoids with contrasting traits. Correlations among each of these traits are independent of body size and phylogeny (Blackburn 1991b).

The oviposition period of $B$. vulgaris at $24^{\circ} \mathrm{C}$ $(30.30 \pm 2.93$ days $)$ was similar to that at $20^{\circ} \mathrm{C}(25.25$ \pm 3.71 days) and longer than that at $30^{\circ} \mathrm{C}(13.55 \pm$ 1.81 days) (Table $\mathrm{I})(\mathrm{F}=19.77 ; P=0.05)$. It was probably due to the increase in temperature that promoted a faster maturing of the sexual organs of female parasitoids, reducing the preoviposition and oviposition periods. Thus, this research showed that the increase in temperature reduced the preoviposition and oviposition periods of $B$. vulgaris females. As such, it is possible that, at $30^{\circ} \mathrm{C}$, the impact of $B$. vulgaris on boll weevil populations occurs earlier.

The fecundity plateau of $B$. vulgaris decreased when the parasitoid was exposed to higher temperatures (Table I). For females exposed to 20,25 and $30^{\circ} \mathrm{C}$, the fecundity plateau started when they reached 11,9 and
3 days, and ended at 28, 27 and 14 days of age, with durations of 17,18 and 11 days, respectively. The declining fecundity period of females of B. vulgaris exposed to 20,25 or $30^{\circ} \mathrm{C}$ started when they reached 29 , 28 and 15 days of age respectively, and ended with death (Table I). The results showed that the increase in temperature promoted an earlier decline in the fecundity of females of B. vulgaris, indicating that this natural enemy is a relatively short-lived parasitoid, with comparatively short preovipositional and fecundity plateau periods. This information is relevant in determining the age when females should be released to produce the highest parasitism of the boll weevil population in the cotton field.

Bracon vulgaris oviposited a mean of $2.82 \pm$ $0.77,7.21 \pm 0.22$ and $5.86 \pm 0.88$ eggs per day during the fecundity plateau period at 20,25 and $30^{\circ} \mathrm{C}$, respectively. This parasitoid is probably a good candidate to be used as a biological control agent against the cotton boll weevil. High fecundity and short preovipositional period allow an adequate numerical response because a female boll weevil oviposits an average of 3.7 and 6.5 eggs per day at 23.9 and $26.7^{\circ} \mathrm{C}$, respectively (Cole and Adkisson 1981).

The number of eggs laid by a female of $B$. vulgaris varied according to the temperature to which it was exposed. B. vulgaris females produced a greater num- 
ber of eggs at $25^{\circ} \mathrm{C}(124.65 \pm 15.27$ eggs/female $)$ than at $20(43.40 \pm 9.58 \mathrm{eggs} / \mathrm{female})$ and $30^{\circ} \mathrm{C}(49.60 \pm$ 8.49 eggs/female) (Table I) $(\mathrm{F}=39.12 ; P=0.05)$. This is the most important point resulted from trade-offs between development time and egg load. The number of eggs laid per female of B. mellitor was 164 at temperatures varying from 27 to $29^{\circ} \mathrm{C}$ (Adams et al. 1969); against 315 of $C$. grandis, when exposed to temperatures of 24 to $27^{\circ} \mathrm{C}$ (Johnson et al. 1973). The number of eggs laid by females of B. kirkpatricki varied from 182.9 (at $25^{\circ} \mathrm{C}$ ) to 87.3 (at $20^{\circ} \mathrm{C}$ ) (Engroff and Watson 1975). The endoparasitoid Diaeretiella rapae (M'Intosh) (Hymenoptera: Braconidae) laid an average of 17 to 29 eggs per female at 20 and $30^{\circ} \mathrm{C}$, respectively (Hayakawa et al. 1990). The variation in temperature probably contributed to the greater production of eggs by $B$. mellitor and $C$. grandis in relation to $B$. vulgaris, since a variation in temperature can offer better reproductive conditions for an insect than a constant temperature.

The number of eggs per female per day was greater at $25^{\circ} \mathrm{C}(3.06 \pm 0.28 \mathrm{eggs} / \mathrm{female} /$ day $)$ than at $20(0.96$ $\pm 0.16 \mathrm{eggs} / \mathrm{female} / \mathrm{day})$ and $30^{\circ} \mathrm{C}(2.66 \pm 0.18 \mathrm{eggs} /$ female/day) (Table I). An increase in temperature promoted an increase in the number of eggs per host larva (Table I). Thus, it is believed that the temperature elevation contributed to the acceleration in the metabolism of $B$. vulgaris, altering the behavior of the females that laid a greater number of eggs in the same paralysed larva, reducing the expenditure of energy. When a female parasitoid selects a host to be parasitized, energy and time are expended in the host paralysation before the host is ready to receive the first egg. If the same female lays two or more eggs in a host, there is a saving of time and energy that would be expended in the process of host paralysation.

The number of parasitized larvae per female of $B$. vulgaris at $25^{\circ} \mathrm{C}(71.75 \pm 6.82)$ was greater than at $20(31.40 \pm 7.40)$ and $30^{\circ} \mathrm{C}(25.15 \pm 4.03)$ (Table I). At $25(1.75 \pm 0.14)$ and $30^{\circ} \mathrm{C}(1.24 \pm 0.18)$, the average number of larvae parasitized by female per day was greater than $20^{\circ} \mathrm{C}(0.69 \pm 0.11)$. During this study, host larvae showed a greater movement when exposed to $25^{\circ} \mathrm{C}$, and less at 20 and $30^{\circ} \mathrm{C}$. This host behavior probably facilitated its location by females of the parasitoid, stimulating them to parasitize fastly. The majority of parasitoids finds their hosts using short and long distance cues, such as vibrations, visual effects and release of kairomones by the host (Strand and Vinson 2008). The braconids, such as $B$. mellitor, use these cues to locate and select their hosts, and are stimulated to oviposit more quickly in those which move (Gerling 1971, Vinson et al. 1976).

The female longevity of $B$. vulgaris was greater at $20(42.60 \pm 4.17$ days $)$ and $25^{\circ} \mathrm{C}(41.10 \pm 2.73$ days $)$ than at $30^{\circ} \mathrm{C}(21.20 \pm 1.67$ days) (Table I). At 20 and $25^{\circ} \mathrm{C}$, the longevity of both sexes was almost two times greater than at $30^{\circ} \mathrm{C}$. The longevity of B. kirkpatricki varied from 60.5 (at $20^{\circ} \mathrm{C}$ ) to 33.2 days (at $35^{\circ} \mathrm{C}$ ) (Engroff and Watson 1975). Males and females of $D$. rapae presented longevity of 6.4 days at $20^{\circ} \mathrm{C}$, and 0.9 days at $30^{\circ} \mathrm{C}$ (Hayakawa et al. 1990). Morales-Ramos and Cate (1992) showed that the longevity of $C$. grandis is 64 and 46 days, respectively, at 25 and $30^{\circ} \mathrm{C}$.

All information generated about the periods of preoviposition, fecundity and attack is important to select the best age at which females of $B$. vulgaris should be released into the cotton ecosystems, aiming at obtaining the highest level of attack on the boll weevil larvae by the female parasitoids.

Life Expectancy Table. B. vulgaris can live until 105, 100 and 50 days when exposed to 20,25 and $30^{\circ} \mathrm{C}$, respectively. For the first 10 days, a life expectancy of 23.5 days is found for $B$. vulgaris exposed to $20^{\circ} \mathrm{C}$, with a $29.8 \%$ risk of this not occurring and, thus, successively until the final observation (101 to 105 days) when there is still a life expectancy of 2.5 days, with an $100 \%$ probability of death in this period. This applies to all temperatures from 25 to $30^{\circ} \mathrm{C}$, in which life expectancy was 44.8 to 15.3 days, with risks of 9.1 and $33.3 \%$ until the final observation (96 to 100 days, and 46 to 50 days), respectively, in which life expectancy for both cases was of 2.3 days, with an $100 \%$ probability of death in the period.

The survival curves for $B$. vulgaris show an abrupt initial fall during the juvenile form, followed by a certain stability, until a new fall at the end of the adult stage (Fig. 1). The behavior shown by the survival data for $B$. vulgaris when exposed to 20,25 and $30^{\circ} \mathrm{C}$, according to Carey (1993), is common for most insects. The analysis of our data revealed a tendency for individuals that were 

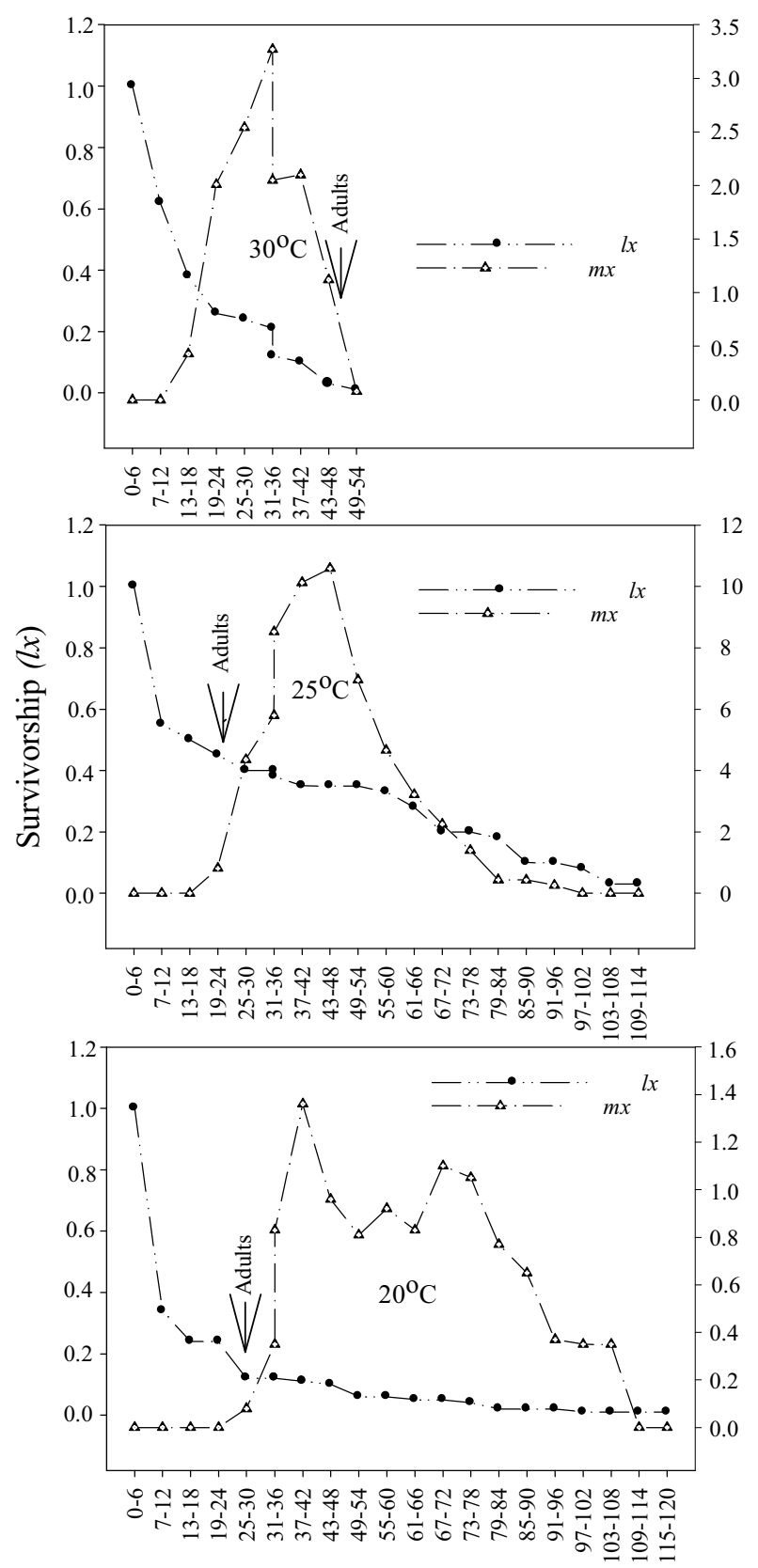

Age class (d)

Fig. 1 - Survivorship $\left(l_{x}\right)$ and natality $\left(m_{x}\right)$ of Bracon vulgaris (Hymenoptera: Braconidae) at 20, 25 and $30^{\circ} \mathrm{C}$. Age class $=5$ days.

exposed to $25^{\circ} \mathrm{C}$ to show greater survival and longevity than at 20 and $30^{\circ} \mathrm{C}$.

Life and Fertility Tables. The fertility data of $B$. vulgaris (Table II) showed that the net reproductive rates $\left(R_{0}\right)$ at 20,25 and $30^{\circ} \mathrm{C}$ were, respectively, 0.68 , 20.67 and 2.47 female progenies that will produce re- productive females in one generation. These values reveal a population growth at 25 and $30^{\circ} \mathrm{C}$. The temperature of $25^{\circ} \mathrm{C}$ has risen more than 30 and 8 times in relation to 20 and $30^{\circ} \mathrm{C}$, respectively, the population increase of B. vulgaris, from one generation to the next. At $20^{\circ} \mathrm{C}$, the net reproductive rate was less than 1 $\left(R_{o}=0.68\right)$, which suggests that this temperature nega- 
TABLE II

Life table parameters of Bracon vulgaris

(Hymenoptera: Braconidae) at three different temperatures.

\begin{tabular}{l|c|c|c}
\hline \multirow{2}{*}{ Parameters } & \multicolumn{3}{|c}{ Temperature $\left({ }^{\circ} \mathrm{C}\right)$} \\
\cline { 2 - 4 } & 20 & 25 & 30 \\
\hline Gross reproductive rate (GRR) & 10.78 & 59.13 & 13.60 \\
\hline Net reproductive rate $\left(\mathrm{R}_{\mathrm{o}}\right)$ & 0.68 & 20.67 & 2.47 \\
\hline Generation time (GT) (day) & 54.68 & 46.62 & 29.16 \\
\hline Doubling time (DT) (day) & -99.54 & 10.67 & 22.34 \\
\hline $\begin{array}{c}\text { Intrinsic rate of increase }\left(\mathrm{r}_{\mathrm{m}}\right) \\
\text { (daily intervals) }\end{array}$ & -0.007 & 0.07 & 0.03 \\
\hline $\begin{array}{c}\text { Finite rate of 1 increase }(\lambda) \\
\text { (daily intervals) }\end{array}$ & 0.98 & 1.18 & 1.07 \\
\hline \multicolumn{2}{|c|}{$(\lambda)$}
\end{tabular}

tively affected the populational growth of the parasitoid. Gross reproductive rates were $10.78,59.13$ and 13.60 eggs per female at 20,25 and $30^{\circ} \mathrm{C}$, respectively.

The time span of a generation (GT) was 54.68 , 46.62 and 29.16 days at 20,25 and $30^{\circ} \mathrm{C}$, respectively, showing that there can be 7, 8 and 13 generations of B. vulgaris per year in these temperatures. The time for females duplicate their populations (DT) at 25 and $30^{\circ} \mathrm{C}$ were 10.67 and 22.34 days, respectively.

The intrinsic rate of population increase $\left(\mathrm{r}_{\mathrm{m}}\right)$ links $\mathrm{R}_{\mathrm{o}}$ and GT and demonstrates the biotic potential of the species (Price 1997). On the other hand, the intrinsic rate of population increase $\left(\mathrm{r}_{\mathrm{m}}\right)$, mean generation time (GT) and doubling time (DT) are useful indices of population growth under a given set of growing conditions (Tsai 1998). The values of $r_{m}$ were 0.07 at $25^{\circ} \mathrm{C}$ and 0.03 at $30^{\circ} \mathrm{C}$, showing that the temperature of $25^{\circ} \mathrm{C}$ produced an increase of $133 \%$ in the value of $r_{m}$ in relation to $30^{\circ} \mathrm{C}$. The interpretation of these values is that the $B$. vulgaris population at 25 and $30^{\circ} \mathrm{C}$ would eventually grow at constant exponential rates of 0.07 and 0.03 per individual per day, respectively. The finite rate of population increase $(\lambda)$ of $1.07\left(25^{\circ} \mathrm{C}\right)$ and $1.03\left(30^{\circ} \mathrm{C}\right)$ reveals the aggregation of more than one individual per female, from one generation to the next.

The proportions of individuals surviving through all immature stages and reaching adulthood $\left(1_{\mathrm{x}}\right)$ were 0.12 at $20^{\circ} \mathrm{C}, 0.45$ at $25^{\circ} \mathrm{C}$ and 0.26 at $30^{\circ} \mathrm{C}$. Thus, an increase of 0.08 at $20^{\circ} \mathrm{C}, 9.30$ at $25^{\circ} \mathrm{C}$ and 0.64 at $30^{\circ} \mathrm{C}$ in the adult progeny per female per generation $\left(l_{x} \times R_{0}\right)$ could be expected under optimal conditions. B. vulgaris reared at $25^{\circ} \mathrm{C}$ showed higher intrinsic rates of increase, which resulted from higher survival and reproductive rate. According to Rabinovich (1978), the adult stage of non-social insects is generally marked by a period without reproduction, followed by a phase of reproduction, when there is commonly a peak period where the reproductive effort is at its maximum, declining rapidly with the females age. This pattern was observed in the fertility curves for $B$. vulgaris at both studied temperatures.

The age-specific reproductive values (RV) provide information that may be useful to decide the optimal age of release of B. vulgaris. In temperatures of 25 and $30^{\circ} \mathrm{C}$, the maximum values of RV were 0.55 and 0.30 , respectively, which are related to the adults of B. vulgaris with approximately five days old. However, at $20^{\circ} \mathrm{C}$, the maximum value of $\mathrm{RV}$ was 0.98 , obtained with adult females of approximately 20 days old. After the beginning of reproduction, the RV may decrease or increase depending on whether fecundity increases faster than the expection of further life decreases. It declines to zero as an individual approaches to its maximum lifespan. Our results suggest that, in biological control programs of A. grandis using innoculative releases whose reductions in boll weevil populations are obtained through the parasitoid progenies, the best age to release B. vulgaris should be that with the highest value of RV, that is, adult females of approximately five days old at 25 and $30^{\circ} \mathrm{C}$, and adult females of 20 days old at $20^{\circ} \mathrm{C}$. However, when inundative releases are necessary, the best age for these releases should be when a high capacity of parasitism occurs (Table I), i.e., between 11 and 31, 9 and 29, and 3 and 14 days old, respectively, at 20,25 and $30^{\circ} \mathrm{C}$. 


\section{ACKNOWLEDGMENTS}

We express our appreciation to the staff at Unidade de Controle Biológico da Embrapa Algodão, especially those responsible for mass rearing the parasitoids and hosts. This research was supported by Financiadora de Estudos e Projetos (FINEP) and Conselho Nacional de Desenvolvimento Científico e Tecnológico (CNPq). We would like to thank the two anonymous referees for valuable comments.

\section{RESUMO}

Estudamos os efeitos da temperatura na reprodução de Bracon vulgaris Ashmead, ectoparasitóide do bicudo-do-algodoeiro, Anthonomus grandis Boheman, em câmaras climatizadas, em temperaturas constantes de 20,25 and $30^{\circ} \mathrm{C}$, umidade relativa do ar de $70 \pm 10 \%$ e fotofase de $14 \mathrm{~h}$. As fêmeas do parasitóide produziram mais ovos a $25^{\circ} \mathrm{C}(124,65$ ovos) do que aquelas expostas a $20(43,40$ ovos $)$ e a $30^{\circ} \mathrm{C}(49,60$ ovos $)$. O número médio de larvas parasitadas por fêmea de B. vulgaris a $25^{\circ} \mathrm{C}$ (71,75 larvas) foi maior do que a $20^{\circ} \mathrm{C}(31,40$ larvas $)$ e $30^{\circ} \mathrm{C}$ $\left(25,15\right.$ larvas). As taxas diárias de aumento $\left(\mathrm{r}_{\mathrm{m}}\right)$ foram $-0,007$ a $20^{\circ} \mathrm{C}, 0,07$ a $25^{\circ} \mathrm{C}$ e 0,03 a $30^{\circ} \mathrm{C}$, indicando que a temperatura de $25^{\circ} \mathrm{C}$ produziu aumento de 1100 e $133 \%$ no valor de $\mathrm{r}_{\mathrm{m}}$ em relação às temperaturas de $20 \mathrm{e} 30^{\circ} \mathrm{C}$, respectivamente. Nos programas de controle biológico do bicudo-do-algodoeiro, usando liberações inoculativas deve-se utilizar fêmeas adultas de B. vulgaris com aproximadamente 5 dias (a 25 ou $30^{\circ} \mathrm{C}$ ) ou 20 dias de idade $\left(\mathrm{a} 20^{\circ} \mathrm{C}\right)$; quando usando liberações inundativas, utilizar fêmeas adultas de $B$. vulgaris, com idade entre 11 e 31 dias $\left(\right.$ a $\left.20^{\circ} \mathrm{C}\right) ; 9$ e $29 \operatorname{dias}\left(\right.$ a $25^{\circ} \mathrm{C}$ ) ou 3 e $14 \operatorname{dias}\left(\right.$ a $\left.30^{\circ} \mathrm{C}\right)$.

Palavras-chave: ectoparasitóide, Anthonomus grandis Boheman, biologia, tabelas de vida e fertilidade.

\section{REFERENCES}

Adams CH, Cross WH ANd Mitchell HC. 1969. Biology of Bracon mellitor, a parasite of the boll wevil. J Econ Entomol 62: 889-895.

ANDREWARTHA HG AND BIRCH LC. 1954. The distribution and abundance of animals. Chicago: The University of Chicago Press, 782 p.

Barfield CS, Bottrell DG and Smith JR JW. 1977. Influence of temperature on oviposition and adult longevity of Bracon mellitor reared on boll weevils. Environ Entomol 6: 133-137.
Beddington CS, Hassell MP AND LaWton JH. 1976. The components of arthropd predation II. The predator rate of increase. J Anim Ecol 45: 165-186.

BLACKBURN TM. 1991a. A comparative examination of life-span and fecundity in parasitoid Hymenoptera. J Anim Ecol 60: 151-164.

BLACKBURN TM. 1991b. Evidence for a 'fast-slow' continuum of life-history traits among parasitoid Hymenoptera. Funct Ecol 5: 65-74.

CAREY JR. 1993. Applied demography for biologists with special emphasis on insects. New York: Oxford University Press, 206 p.

Cole CL And AdKisson PL. 1981. Life history and fecundity of the boll weevil reared in constant and variable temperature regimens. Southwest Entomol 6: 298-303.

ENGROFF BW AND WATSON TF. 1975. Influence of temperature on adult biology and population growth of Bracon kirkpatricki. Ann Entomol Soc Am 68: 1121-1125.

GERLING D. 1971. Occurrence, abundance and efficiency of some local parasitoids attacking Spodoptera littoralis (Lepidoptera: Noctuidae) in select cotton fields in Israel. Ann Entomol Soc Ama 64: 1373-1379.

Hance T, BaAren JV, Vernon P and Boivin G. 2007. Impact of extreme temperatures on parasitoids in a climate change perspective. Annu Rev Entomol 52: 107-126.

HAYAKaWA DL, GRAFuis E AND STEhr FW. 1990. Effects of temperature on longevity, reproduction and development of the asparagus aphid (Homoptera: Aphididae) and the parasitoid, Diaeretiella rapae (Hymenoptera: Braconidae). Environ Entomol 19: 890-896.

JERVis MA, Ellers J AND HARVEy JA. 2008. Resource, acquisition, allocation, and utilization in parasitoid reproductive strategies. Annu Rev Entomol 53: 361-385.

Johnson WL, Cross WH, McGovern WL AND MitCHELL HC. 1973. Biology of Heterolaccus grandis in a laboratory culture and its potential as an introduced parasite of the boll weevil in the United Stated. Environ Entomol 2: 112-118.

Kalaitzaki AP, LyKouressis DP, Perdikis DC AND ALEXANDRAKIS VZ. 2007. Effect of temperature on development and survival of the parasitoid Pnigalio pectinicornis (Hymenoptera: Eulophidae) reared on Phyllocnistis citrella (Lepidoptera: Gracillariidae). Environ Entomol 36: 497-505.

KREBS CJ. 1994. Ecology: The experimental analysis of distribution and abundance. New York: Harper \& Row, $801 \mathrm{p}$. 
LOTKA AJ. 1907. Studies on the mode of growth of the material aggregates. Am J Sci 24: 199-216.

Morales-RAmos JA AND CATE JR. 1992. Laboratory determination of age-dependent fecundity, development, and rate of increase of Catolaccus grandis (Burks) (Hymenoptera: Pteromalidae). Ann Entomol Soc Am 85: 469-476.

PRICE PW. 1997. Insect ecology. New York: J Wiley \& Sons, $874 \mathrm{p}$.

RABINOVICH JE. 1978. Ecologia de poblaciones animals. Secretaria General de la Organización de los Estados Americanos, $114 \mathrm{p}$.

RAmalho FS, GonZaga JV AND SILVA JRB. 1993. Métodos para determinação das causas de mortalidade natural do bicudo do algodoeiro. Pesqui Agropecu Bras 28: 877-887.

RAmalho FS AND WANDERLEY PA. 1996. Ecology and management of cotton boll weevil in South America cotton. Am Entomol 42: 41-47.

Ramalho FS, Wanderley PA, Malaquias JB, Rodrigues KCV, SOUZA JVS AND ZANuncio JC. 2009. Temperature-dependent development rates of Bracon vulgaris, a parasitoid of boll weevil. Phytoparasitica 37: 17-25.

Ramalho FS, WANDERley PA And SAntos TM. 1996. Natural enemies and programs of biological control of cotton boll weevil in Brazil. In: STADLER T (Ed), Workshop Proceedings "Integrated Pest Management of the Cotton Boll Weevil in Argentina, Brazil and Paraguay", p. $142-148$.
REZNIK SYA, VoINOVICH ND AND VAGHINA NP. 2009. Effect of temperature on the reproduction and development of Trichogramma buesi (Hymenoptera: Trichogrammatidae). Eur J Entomol 106: 535-544.

Southwood TRE. 1968. Ecological methods. London: Chapman \& Hall, 368 p.

STRAND MR AND Vinson SB. 2008. Source and characterization of an egg kairomone of Telenomus heliothidis, a parasitoid of Heliothis virescens. Physiol Entomol 7: 83-90.

TSAI JH. 1998. Development, survivorship and reproduction of Toxoptera citricida (Kirkaldy) (Homoptera: Aphididae) on eight host plants. Environ Entomol 27: 1190-1195.

VINSON SB, HENSON RD AND BARFIELD CS. 1976. Ovipositional behavior of Bracon mellitor Say (Hymenoptera: Braconidae), a parasitoid of bool weevil (Anthonomus grandis Boh.) I. Isolation and identification of a sinthetic releaser of ovipositor probing. J Chem Ecol 2: 431-440.

WANDERLEy PA AND RAMAlho FS. 1996. Biologia e exigências térmicas de Catolaccus grandis (Burks), parasitóide do bicudo-do-algodoeiro. Pesqui Agropecu Bras 31: 237-247. 